\title{
Diferentes vivências: a Revolta dos Colonos de 1957 em Verê/PR
}

\section{Different experiences: the 1957 Colonists Revolt in Verê/PR}

\author{
Tiago Arcanjo Orben*
}

\begin{abstract}
Resumo
Este artigo apresenta distintas percepções sobre a Revolta dos Colonos de 1957, ocorrida no Sudoeste do Paraná. O levante envolveu diferentes interesses, no campo social, político e econômico. Tais aspectos inserem-se em um contexto específico de disputas pela terra na região. Assim, neste artigo o objetivo é refletir narrativas de personagens que participaram ou vivenciaram a Revolta dos Colonos no município de Verê. Por meio da história oral são apresentadas as experiências de sujeitos que viveram o período ou presenciaram o conflito social, destacando suas trajetórias de vida, seus modos de viver e lutas na terra. A discussão procura privilegiar os sujeitos da Revolta, pessoas sem vínculos com partidos políticos, que não participaram de manifestações comemorativas, mas que possuem muitas memórias a apresentar sobre suas trajetórias de vida. Essas memórias são distintas da Revolta vista por meio de uma memória comemorativa, que além de exaltar de diferentes formas inúmeros sujeitos do meio público político, exclui e minimiza a presença dos colonos, que aqui são entendidos e apresentados como protagonistas de suas conquistas.
\end{abstract}

Palavras-chave: Sudoeste do Paraná; História oral; Experiências sociais; Memória.

\begin{abstract}
This paper presents several readings regarding the 1957 Settler Revolt, which occured in Southwestern Paraná. This conflict involved many concerns, both on the social, political or economical areas. These aspects hapenned within a specific land dispute context in the region. Therefore, this research has aims at thinking over several narratives of historical characters who participated or lived the Settler Revolt. Through oral history it is possible to expose the experience of people who were there, regarding the social conflicts, and this paper aims to highlight their life course as well as how they see those fights for land. The discussion tries to privilege the people who had no political
\end{abstract}

\footnotetext{
* Doutorando em História pelo Programa de Pós-Graduação em História da Pontifícia Universidade Católica do Rio Grande do Sul. E-mail: tiagoaorben@gmail.com
} 
party bonds and did not participate in commemorative events, but have many memories to present concerning their live courses. Theses memories are different from those seen from a commemorative perspective, that not only glorify in many ways countless political party people but exclude and do not take into account the settlers, who are here understood and presented as leading figures of their own achievments.

Keywords: Paraná Southwestern; Oral History; Social Esperiences; Memory.

\section{Introdução}

Este artigo privilegia memórias de remanescentes do conflito social de 1957, ocorrido no Sudoeste do estado do Paraná, o qual, dentre inúmeras definições, ficou mais conhecido como Revolta dos Colonos ou Posseiros. Neste sentido, destaco as experiências dos remanescentes deste conflito com atenção especial aos protagonistas desta conquista no município de Verê. Assim, procuro considerar como os entrevistados ao mesmo tempo em que rememoram aquele período como "difícil" na conquista da terra, também apresentam vivências felizes no viver em comunidade, nas quais prevalecem os laços de amizade e parentesco no superar das dificuldades e nos momentos de lazer.

A Revolta de 1957, ${ }^{1}$ ocorrida no Sudoeste do Paraná, é um levante popular, em que colonos, reconhecidos enquanto posseiros, conquistam suas propriedades. Em um contexto em que as lutas camponesas começam a ter destaque no Brasil, os colonos obtêm sucesso, contrariando o cenário que se apresentava em nível estadual e nacional para o período.

O movimento envolveu colonos e companhias colonizadoras, em especial a Clevelândia Industrial e Territorial Ltda (CITLA), além de suas subsidiárias Apucarana e Comercial. Essas empresas, com o respaldo do então governador do estado do Paraná Moysés Lupion, se diziam detentoras das terras

\footnotetext{
${ }^{1}$ Este movimento social possui um denso material historiográfico, entre os mais significativos estão os seguintes trabalhos: AMÂNCIO, Silvia Maria. Ontem, luta pela terra; hoje, monumento histórico: A Revolta dos Posseiros no Sudoeste do Paraná em suas variadas versões. Maringá/PR: Dissertação - Mestrado em História, Universidade Estadual de Maringá-UEM, 2009. GOMES, Iria Zononi. 1957: A Revolta dos Posseiros. 3ํe.. Curitiba, Criar Edições, 2005. LAZIER, Hermógenes. Análise Histórica da Posse de Terra no Sudoeste Paranaense. 3. ed. Francisco Beltrão, GRAFIT Gráfica e Editora Ltda, 1998. PEGORARO, Éverly. Dizeres em confronto: A Revolta dos Posseiros de 1957 na imprensa paranaense. 1 ed.. Guarapuava/PR, Unicentro, 2008. WACHOWICZ, Ruy Christovam. Paraná, Sudoeste: ocupação e colonização. 2. ed.. Curitiba, Lítero-Técnica, 1985.
} 
ocupadas e, desta forma, efetuavam a cobrança das tais pela segunda vez, pois, muitos já haviam pago pela fração de terra quando chegaram a região.

Os colonos eram incentivados a migrar para a região em grande medida a partir do ano de 1943, com a criação da CANGO - Colônia Agrícola Nacional General Osório, que tinha como objetivo "colonizar" as terras em questão, o que acontece com mais vigor no início dos anos 50, com a chegada de inúmeras famílias do Rio Grande do Sul, Santa Catarina e de outras regiões do Paraná. Com isso, em vista a intensificação das cobranças, tanto através de corretores, como por meio de jagunços - de forma violenta - em setembro e outubro de 1957 os colonos se veem obrigados a estabelecer levantes contra as companhias de terras. Organizados em governos populares e mediados em Francisco Beltrão e Pato Branco pelas rádios Colmeia, o movimento atinge seu auge nos dias 09, 10, 11 e 12 de outubro, nos conglomerados mais importantes na época: Pato Branco, Francisco Beltrão, Capanema e Santo Antonio do Sudoeste. ${ }^{2}$

Após os levantes - com a ocupação dessas localidades pelos colonos - as companhias são obrigadas a se retirar e os colonos conseguem a legalização da terra na década de 1960 com a criação do GETSOP - Grupo Executivo para as Terras do Sudoeste do Paraná, o qual encerra suas atividades na década de 70 após ceder o título da terra aos colonos. ${ }^{3}$

Dada a complexidade dos acontecimentos envolvendo colonos e companhias colonizadoras, bem como interesses políticos no cenário estadual e nacional, não será trabalhado diretamente os antecedentes e principais episódios que desencadeiam no levante de 1957, isso levando em consideração uma maior atenção às vivências dos entrevistados.

Desta forma, a partir da metodologia da história oral, durante a pesquisa - que deu base para a construção deste artigo - foram realizadas 05 entrevistas no município de Verê. Além de outras 11 entrevistas do ano de 2011. ${ }^{4}$ Essas entrevistas serviram de parâmetro para a reflexão desenvolvida, analisando como essas vivências se diferenciam daquilo que é apresentado sobre o levante em algumas historiografias e comemorações. Ou seja, existem

\footnotetext{
${ }^{2}$ GOMES, Iria Zononi. 1957: A Revolta dos Posseiros. 3 ed.. Curitiba, Criar Edições, 1986. ${ }^{3}$ Ibidem.

${ }^{4}$ Estas entrevistas foram realizadas durante o ano de 2011 como parte do Projeto de extensão intitulado: Memórias da terra: Modos de viver, lutas e resistências camponesas no Oeste e Sudoeste do Paraná. Coordenado pelo professor Dr. Paulo José Kolling e os acadêmicos do curso de História da Universidade Estadual do Oeste do Paraná - Unioeste, Tiago A. Orben e Franciele Pinheiro.
} 
diferentes versões ou grupos que reivindicam para si a luta de 1957, cada qual exalta figuras específicas, que se consolidam como ícones do movimento.

O objetivo aqui não é desqualificar ou ignorar a Revolta nos outros municípios da região Sudoeste do Paraná, tampouco supervalorizar o levante somente junto às vivências aqui apresentadas como pertencentes ao todo. Em sentido diverso, o privilegiar de memórias pertencentes à Verê acontece na tentativa de demonstrar a diversidade e amplitude que a Revolta de 1957 teve nessa região, ao ponto de possibilitar à historiografia observar de diferentes perspectivas um movimento social, que tinha como objetivo comum a conquista da terra.

A metodologia da história oral foi de extrema importância na pesquisa. O método foi aplicado junto à história oral temática, quando se sugeria aos entrevistados um relato de sua experiência de vida. Embora a metodologia seja aplicada na perspectiva temática, sugeria-se uma descrição ampla de sua vida, percebendo de que forma o conflito de 1957 ou a conquista da terra apareceram em suas experiências.

\section{Vivências felizes em um "período difícil": memórias do levante de 1957 no município de Verê/PR}

Ao considerar o uso da fonte oral enquanto metodologia no trabalho historiográfico procuro pensar como ela, junto à memória, apresenta possibilidades de reflexões na análise das fontes orais. Neste sentido, aponto algumas informações com relação às principais discussões teóricas e metodológicas em relação ao tema e de que forma tais aspectos se relacionam com as memórias dos entrevistados privilegiados neste artigo.

Henri Bergson em seu trabalho Matéria e memória: Ensaio sobre a relação do corpo com o espírito, procura refletir sobre a relação da mente com o mundo exterior, centrando suas considerações na relação entre a percepção (mente) e as ações do nosso cérebro. Desta forma, aconteceria a construção entre a materialidade do mundo e a percepção ou a mente.

Bergson diferencia "percepção" de "lembrança", e destaca que sempre completamos a percepção com a lembrança, ou seja, não conseguimos produzir uma percepção completa, mas, sim, somente com ajuda dos quadros fornecidos pela memória. Ao ponderar essas questões com um exemplo mais prático, Bergson nos faz considerar que temos uma memória que "armazena tudo", da mesma forma que temos uma consciência prática que decide aquilo que devemos lembrar ou conservar. 
Para refletir algumas questões, destaco um exemplo de frase comum quando estabelecido o primeiro contato com um entrevistado ao afirmar que: "não tenho do que falar", ou que "já nem lembra quase mais nada do passado".

Ao me deparar com esta situação, recorro a vários mecanismos para incitar o entrevistado a conceder seu relato. Quando percebo que a entrevista não está "fluindo", recorro a um método com que na maioria dos casos obtenho sucesso. Trata-se do uso de fotografias, interrogo se o entrevistado possui fotografias relacionadas ao tema, no caso a Revolta de 1957, ou mesmo de sua vida, e é neste momento que a maioria das entrevistas "deslancha" para longas conversas recheadas de lembranças, em que o próprio entrevistado se surpreende em recordá-las novamente.

Como uma resposta para isso apenas apresento um trecho do trabalho de Bergson, em que considera a percepção junto às lembranças:

Na verdade, não há percepção que não esteja impregnada de lembranças. Aos dados imediatos e presentes de nossos sentidos misturamos milhares de detalhes de nossa experiência passada. Na maioria das vezes, estas lembranças deslocam nossas percepções reais, das quais não retemos então mais que algumas indicações, simples "signos" destinados a nos trazerem à memória antigas imagens. ${ }^{5}$

Somente o destacar que "não há percepção que não esteja impregnada de lembranças" pode explicar o sucesso de minha experiência para com a memória dos entrevistados. Seu presente, ou sua percepção, está repleto de lembranças armazenadas, que são recordadas a partir do "link" que o cérebro estabelece com a fotografia. Elas trazem "milhares de detalhes de nossa experiência passada", que fazem o personagem refletir não apenas junto às lembranças, mas também do presente. Com Bergson, consigo visualizar o sucesso que tenho com essa metodologia, que explica de que forma nossa percepção incitada por imagens reaviva lembranças antes distantes. ${ }^{6}$

É possível observar estas questões na entrevista concedida pelo senhor Osvaldo Ferreira da Silva, ${ }^{7}$ que ao conhecer minha pesquisa decide guiar seu depoimento a questões relacionadas ao litígio da terra na década de 50, ou seja, relaciona sua memória ao motivo que ele acredita ter me levado a

\footnotetext{
${ }^{5}$ BERGSON, Henri. Matéria e memória: ensaio sobre a relação do corpo com o espírito. São Paulo: Martins Fontes, 1990, p. 22.

${ }^{6}$ Ibidem, p. 30.

${ }^{7}$ Osvaldo é natural de Lindóia, município de Concórdia, Santa Catarina. Nasceu no dia 12 de junho de 1940, está hoje com 75 anos, reside no município de Verê-Pr desde o ano de 1956, quando, aos 16 anos, sua família migra de Santa Catarina para o Paraná.
} 
lhe entrevistar e não diretamente as questões sugeridas no transcorrer da entrevista.

Percebo que suas respostas são direcionadas ao conflito, mesmo quando questiono sobre suas vivências em Concórdia, Osvaldo opta por não falar muito. Apesar disso, interrogo como foi migrar para a região:

[...] nós viemos com a família inteira, viemos, no tempo das companhias que cheguemos aí. Naquele, as companhias começaram no fim do ano, eu acho, mês de setembro em diante e nós cheguemos dia 20 de junho ali na Barra Verde [comunidade rural do município de Verê]. o pai comprou ali. ${ }^{8}$

O presente trecho demonstra a preocupação do entrevistado em localizar a migração de sua família para a região em um momento de instabilidade social. Suas vivências são apresentadas com referência ao pai, o qual decide migrar no intuito de conseguir um solo mais fértil para cultivo, o que fica claro ao demonstrar a preocupação para com o plantio ao chegar à região:

Quando nós cheguemos aqui era roça de mato, tinha desmatado uns três alqueires, que plantemos trigo naquele ano, cheguemos ali ainda plantemos trigo. Cheguemos dia 20 de junho e semeemos duas bolsas de trigo e depois fizemos roça de mato, naquela época. ${ }^{9}$

Osvaldo demarca as principais dificuldades encontradas na região para além do litígio da terra. Suas experiências são apresentadas no sentido da dificuldade, mesmo quando não apresenta considerações em relação a problemas enfrentados com as companhias, destaca vivências difíceis no dia a dia para além do litígio da terra.

Assim como infere Bergson "uma vez que a percepção pura nos dá o todo ou ao menos o essencial da matéria, uma vez que o restante vem da memória e se acrescenta à matéria, é preciso que a memória seja, em princípio, um poder absolutamente independente da matéria". ${ }^{10}$ Tais considerações sinalizam como o autor considera em essência a percepção e a memória em relação à matéria ou ao "mundo exterior". Para Bergson a percepção nos dá a matéria, ou "o essencial", o restante advém da memória e completaria a matéria ou o sentido que atribuímos àquela realidade. Para seu Osvaldo, o

\footnotetext{
${ }^{8}$ FERREIRA DA SILVA, Osvaldo. Entrevista concedida ao Projeto de Pesquisa: A Revolta dos Colonos outras memórias. Por Tiago A. Orben. Comunidade rural, Linha Nossa Senhora da Salete, Verê/PR, 20 de maio de 2013, duração: 56 min. 2 seg. p. 2.

${ }^{9}$ Ibidem, p. 3.

${ }^{10}$ BERGSON, Henri. Matéria e memória: ensaio sobre a relação do corpo com o espírito. São Paulo, Martins Fontes, 1990, p. 77.
} 
sentido de lamentação e dificuldade é complementado com os mementos difíceis para além do litígio da terra, nas vivências cotidianas.

Em sentido diverso, a memória apresenta-se enquanto um meio totalmente independente da matéria, ou seja, o cérebro não representa o mundo. Por meio da memória dos entrevistados, eles "reconstituem" o passado a partir dos quadros fornecidos no presente. Assim, funciona como um instrumento de ação, quando elaboro um questionamento a seu Osvaldo, sua memória através da percepção do presente acrescenta-se à matéria, o que constitui suas lembranças com a ação de reconhecimento ou percepção na operação e consequentemente reprodução.

Estas questões se repetem quando questiono "como era a região quando chegou", o que o faz estabelecer as péssimas condições de acesso à localidade onde sua família fora residir. "A região era meio difícil, fazer estrada, derrubar mato ou limpar". ${ }^{11}$ Suas considerações relacionadas às dificuldades e ao sofrimento se apresentam ainda quando aponta para a necessidade dos próprios moradores em fazer estradas:

Fizemo estrada, a serra ali foi nós que fizemos, [referindo-se a uma serra, localizada na estrada que dá acesso a sua residência à cidade de Verê] detonemos ai uns, parece que 14 dinamites nas pedras e abrimos a estrada, daí subia carroça. Ai os outros moradores aqui de cima ajudaram nós, o Afonso Estanger, o véio Casol veio ajudar, que ficava mais perto pra eles sair pro planalto. ${ }^{12}$

Apesar de ser sucinto em considerações relacionadas a esta questão, neste trecho destaco as vivências comunitárias. Osvaldo apresenta constantemente o viver em comunidade, e o quanto a ausência do Estado era suprida com os laços estabelecidos entre os moradores de comunidades próximas ou da mesma comunidade. 0 entrevistado apresenta nessas vivências a importância da ajuda mútua, destacando que todos se ajudavam na medida do possível. Assim, seu depoimento é caracterizado como um período difícil não apenas quando destaca os acontecimentos envolvendo a questão agrária, mas também nas diversas situações enfrentadas no dia a dia. Quase ao fim da entrevista interrogo novamente: “como é que era viver aquele período?". E com ênfase seu Osvaldo assinala: "Era... tinha que trabalhar!". ${ }^{13}$ Optou por não falar novamente dos acontecimentos de 1957, e caracterizou o período vivenciado como "difícil" no trabalho diário, para além da indefinição jurídica da terra.

\footnotetext{
${ }^{11}$ FERREIRA DA SILVA, op. cit., p. 3.

${ }^{12}$ Ibidem, p. 3.

${ }^{13}$ Ibidem, p. 12.
} 
Conforme apresentado, o depoimento se caracteriza por seu constante direcionar aos acontecimentos envolvendo o pleito da terra, direcionamento que se volta com frequência ao superar de dificuldades; suas memórias são de superação, mesmo quando não é indagado sobre o litígio da terra as mesmas dificuldades apresentadas nesta questão parecem perpassar os demais pontos abordados na entrevista. O que deve ser posto ao lado de suas respostas em relação à "chegada à região" e às "vivências comunitárias" é o fato de essas serem mais sucintas, ao passo que quando interrogado em relação aos episódios de 1957, seu depoimento se prolonga para longos relatos.

Neste sentido, ainda em relação às questões envolvendo a memória junto ao depoimento de seu Osvaldo, destaco Maurice Halbwachs, que a trabalha enquanto reconstrução. O raciocínio de Halbwachs reflete a recordação ou as lembranças a partir dos contextos sociais, suas reflexões inserem-se naquilo que ele denomina de "quadros sociais da memória", sua discussão não é somente a memória propriamente dita, mas também, o que dela deriva, ou, seus "quadros sociais".

Nesta linha de raciocínio, cabe destacar seu trabalho, A memória coletiva, no qual traz algumas das suas discussões com relação ao esquecimento. Halbwachs considera que a memória individual se faz social ou coletivamente, defendendo uma articulação em que se coloca a memória coletiva e individual, entre o indivíduo e a sociedade. Ecléa Bosi, em seu trabalho, Memória e sociedade. Lembranças de velhos, em poucas páginas expressa o raciocínio deste autor, apontando que: "O caráter livre, espontâneo, quase onírico da memória é, segundo Halbwachs, excepcional. Na maior parte das vezes, lembrar não é reviver, mas refazer, reconstruir, repensar, com imagens e idéias de hoje, as experiências do passado". ${ }^{14}$

Esta perspectiva apresentada por Halbwachs de que toda memória individual é coletiva e se constitui junto ao social também foi explorada pelos trabalhos de Michael Pollak e Paul Ricoeur. ${ }^{15}$ Assim, não se pode negar sua contribuição para os estudos com relação à memória, principalmente neste "reconstruir ou repensar". Ou seja, em Bergson temos uma perspectiva de construção por meio da percepção e das questões psíquicas, já Halbwachs a

\footnotetext{
${ }^{14}$ BOSI, Ecléa. Memória e Sociedade. Lembranças de velhos. São Paulo, Companhia das Letras, 1994, p. 17. ${ }^{15}$ POLLAK, Michael. "Memória, esquecimento, silêncio". In: Estudos históricos. Rio de Janeiro, CPDOC/FGV, 1989, v. 2, n. 3. POLLAK, Michael. "Memória e identidade”. In: Estudos históricos. Rio de Janeiro: CPDOC/ FGV, 1992, v. 5, n. 10. POLLAK, Michael. Memória, olvido, silencio: La producción social de indentidades frente a situaciones limite. La Plata/Buenos Aires, Al Margen, 2006. RICOEUR, Paul. A memória, a história, o esquecimento. Campinas, UNICAMP, 2007.
} 
reflete no social, a partir de uma memória coletiva, e ao mesmo tempo individual, enquanto reconstrução.

Com isso, apresento um pequeno trecho em que Halbwachs destaca alguns aspectos em relação às lembranças e o seu sentido social ou coletivo:

Mas nossas lembranças permanecem coletivas, e elas nos são lembradas pelos outros, mesmo que se trate de acontecimentos nos quais só nós estivemos envolvidos, e com objetos que só nós vimos. É porque, em realidade, nunca estamos sós. Não é necessário que outros homens estejam lá, que se distingam materialmente de nós: porque temos sempre conosco e em nós uma quantidade de pessoas que não se confundem. ${ }^{16}$

Como primeiro aspecto, cabe destacar que para o autor nossas lembranças permanecem coletivas e são lembradas também pelos outros, mesmo que estivéssemos sós. Isso se justificaria porque para Halbwachs "nunca estamos sós", mesmo que chegássemos a um local em que nunca estivemos antes, a construção elaborada por outras pessoas que já estiveram lá e também por imagens colaboram para as impressões e conclusões que formulamos sobre aquele local antes desconhecido. A tese de Halbwachs é que, mesmo estando a sós em um lugar nunca antes visitado, nossa memória pode ser coletiva, pois se relaciona com aquilo que vivemos antes daquele presente.

Relaciono essas colocações de Halbwachs à continuidade do depoimento de seu Osvaldo. Quando lhe interrogo sobre os acontecimentos de 1957, reserva longos relatos aos episódios vividos, tanto por ele e seu círculo familiar, quanto aos eventos que não envolveram diretamente sua família, mas que suas lembranças pensadas coletivamente o permitem constituir. Elabora sua memória não apenas com suas vivências e de seu círculo familiar, mas também junto a "quadros sociais" apresentados ao entrevistado.

Assim, apresento a importância que a conquista da terra e as dificuldades deste processo tiveram. Pois quando questiono "como foi a questão da terra em 1957?", pouco interfiro, e noto o quanto isso foi marcante em sua trajetória e de sua família:

É em 56 pra 57 foi a questão da terra. Que as companhias se instalaram no Verê foi eu acho que setembro de 56 e daí elas ficaram de posse das terras, a gente era posseiro, faziam os colonos requerer a terra naquela época. 0 pai requereu a terra ali e deu 3 mil reais naquele tempo, que tinha sobrado que tinha trazido, pras companhias, em sinal de negócio, que eles exigiam um pouco de dinheiro,

${ }^{16}$ HALBWACHS, Maurice. A memória coletiva. São Paulo, Vértice, 1990, p. 26. 
pra muitos eles não exigiam, ai o pai ofereceu daí eles fizeram o preço fixo, fizeram contrato e... O pai deu o dinheiro pra eles não incomodá mais. ${ }^{17}$

Neste fragmento destaco o reconhecimento de seu Osvaldo enquanto colono posseiro, e que nesta situação são "obrigados" a "requerer a terra". Apresenta esse requerer como pagar certa quantia em dinheiro para as companhias, e que seu pai teria pago a importância de 3 mil reais para "eles não incomodá mais".

Além das questões elencadas acima, quando Osvaldo descreve os acontecimentos de 1956 e 1957, também faz transparecer o clima de instabilidade, o qual era amenizado nas vivências em comunidade fundamentadas na ajuda mútua. Isso acontece no momento em que apresenta o apoio de um colono conhecido como "Vasco". Ele teria auxiliado seu irmão Júlio quando este estava doente, além disso, teria alertado para os perigos da instabilidade política e social:

O que apoiô os colonos, que apoiava era o falecido Pedrinho e o Vasco, um que tinha uma camioneta, aquele Vasco, aquele alemão, depois logo foi embora, que mataram o falecido Pedrinho. Até ele foi levar o Júlio que tinha uma inflamação em uma perna, daí o pai disse: "vamos levar no doutor Walter em Beltrão", diz: [vasco] “oia seu Ernesto lá é perigoso, não posso ir com a camioneta lá, eles me conhecem". Ele tava com medo, o Vasco aquele. Não tinham matado o falecido Pedrinho ainda, mataram no outro dia, daí disse: "vamos a Pato Branco", e o pai foi pra Pato Branco, ele quis ir, levô o Júlio no hospital em Pato Branco, daí o pai tava com o Júlio no hospital e soube que tinham matado o falecido Pedrinho no outro dia, e o pai foi lá na câmera de vereadores onde é que tavam velando ele, o pai foi lá vê o corpo dele. Foi no velório, o pai tava lá em Pato Branco. ${ }^{18}$

Neste trecho, a realidade vivida pela família de Osvaldo entrelaça-se a um importante momento da Revolta. Além disso, ganha destaque o reconhecimento que o "falecido" vereador Pedrinho Barbeiro tinha para com os colonos, e o quanto o viam como um representante. Mas, mais do que o reconhecimento do vereador, Osvaldo destaca o apoio de um nome oculto, que após o assassinato de Pedrinho Barbeiro abandona a região, o "Vasco", "aquele alemão", como o caracteriza, um homem de confiança dos colonos, e que aconselha corretamente seu pai a levar Júlio até Pato Branco, e não a Francisco Beltrão. Mais do que as lembranças das vivências de sua família, seu Osvaldo recorda aspectos ignorados ou que ganham pouco destaque na

\footnotetext{
${ }^{17}$ FERREIRA DA SILVA, op. cit, p. 5.

${ }^{18}$ Ibidem, p. 8.
} 
historiografia, como o abandono da região que o medo e a insegurança causados pelas companhias e seus jagunços causaram a muitos colonos.

Ao elencar estas questões ainda com referência a Halbwachs destaco "o esquecimento pelo desapego de um grupo", que condiciona a lembrança aos laços estabelecidos com determinado grupo social. Em um de seus exemplos cita como um professor e sua turma de alunos podem ter distintas formas de recordar acontecimentos vividos juntos. Em suma, o exemplo de Halbwachs é que o professor, depois de alguns anos sem ter contato com os seus antigos alunos, tende a esquecer nomes e acontecimentos vividos naquela turma, mantendo na memória apenas aqueles que considerou mais significativos. Ao mesmo tempo, os alunos, também com o passar do tempo, tendem a esquecer algumas experiências vividas nas aulas com aquele professor, com ressalva para aquelas mais significativas para si. ${ }^{19}$

Desta forma, assim como a memória se constituiria no social ou das vivências em grupo, o esquecimento também aconteceria no social ou, no caso, do desapego de determinado grupo. Nestes itens Halbwachs apresenta por meio de exemplos como a memória pode ser coletiva, tanto ao constituir-se através das lembranças quanto no esquecimento.

Mas, para refletir sobre outras questões apresentadas pelo autor, e também relacionando os exemplos de Halbwachs com minha experiência no trabalho com fontes orais, destaco outro trecho, em que apresenta como age a memória no "quadro da lembrança", a partir da relação do tempo ao enquadrar a lembrança:

Acontece também que não reconstituímos o quadro temporal senão depois
que a lembrança foi restabelecida e então somos obrigados, a fim de localizar
a data do acontecimento, dele examinar em detalhes todas as partes. Mesmo
assim, já que a lembrança conserva os traços do período ao qual se reporta, este
só foi lembrado talvez, porque havíamos vislumbrado esses traços, e pensado
no tempo em que o acontecimento se realizou. A localização, aproximativa e
muito imprecisa de início, definiu-se em seguida quando a lembrança estava
presente.

A consideração que o autor propõe neste ponto é a relação entre a lembrança e o quadro temporal. Para Halbwachs só restabelecemos o quadro temporal depois que estabelecemos o primeiro contato com o acontecimento por meio da lembrança. Desta forma, leva em consideração os traços do período a que se reporta. Com isso, se restabelece o quadro temporal em que o

\footnotetext{
${ }^{19}$ HALBWACHS, Maurice. A memória coletiva. São Paulo: Vértice, 1990. p. 29, 30 e 31.

${ }^{20}$ Ibidem, p. 101.
} 
acontecimento se realizou. Em um exemplo mais prático, quando um dos meus entrevistados se recorda de sua infância, primeiro ele localiza onde morava, por exemplo, no Rio Grande do Sul ou no Paraná, posteriormente associa esta lembrança ao quadro temporal, ou seja, recorda o ano em que migrou para outra região, e aí pode concluir a data da infância a partir da lembrança de onde o acontecimento se realizou.

Esses aspectos podem ser percebidos no depoimento de Dona Inês Moraes Guandalin ${ }^{21}$ que expõe muitas vivências felizes, principalmente associadas a seu falecido marido. Sua entrevista fica muito caracterizada por isso, quando relata momentos como sua infância, momentos vividos em família ou mesmo de quando conheceu seu falecido marido. Sempre apresentava um semblante feliz, na maioria das vezes descrevendo em meio a sorrisos. Por outro lado, quando relata acontecimentos relacionados ao levante é mais sucinta, e apresenta um olhar mais triste, com um semblante sério, como se estivesse vivendo novamente o acontecido.

Nessa linha de argumentação, dona Inês, em um dos momentos mais felizes de seu depoimento, relata como conheceu seu marido, apresentando com muito bom humor e uma visível emoção uma memória feliz vivida em um período que ela também caracteriza como difícil. Desta forma, quando indagada "como conheceu seu marido?", responde:

Ah eu conheci numa festa lá perto da casa deles, nós tava passeando por lá, mas naquela época não deu o namoro. Naquela época só conversamos numa festa, pra lá e pra cá, porque onde se encontrava era assim, numa festa, passear: “vamos passear? Então tá vamos passear..." passeava, conversava deu, deu, não deu, não deu. Ai não deu nada, ele foi embora pra [...].22

Dona Inês acrescenta que, além das conversas dominicais "depois da missa", também encontravam seus namorados ou futuros pretendentes em raras festas comunitárias, em que os namoros iniciavam-se com o "passear". Deste modo, apresenta que em uma dessas festas conheceu seu Jardelino,

\footnotetext{
${ }^{21}$ Inês Moraes Guandalin, natural de Criciúma Santa Catarina, professora aposentada. Na década de 50 vivenciou enquanto educadora a Revolta. Sua entrevista foi realizada no ano de 2011, como parte do Projeto Memórias da Terra: Modos de viver lutas e resistências camponesas no Oeste e Sudoeste do Paraná. A entrevista foi realizada pela equipe do projeto, que naquele dia, além da minha presença, também contava com a acadêmica Francieli Pinheiro e o professor Paulo José Koling. Dona Inês tem uma rica experiência também associada a seu falecido marido, senhor Jardelino Guandalin, que havia participado dos eventos de 1957 e tinha uma amizade muito próxima com o vereador Pedrinho Barbeiro assassinado por jagunços da companhia CITLA.

${ }^{22}$ GUANDALIN, Inês Moraes. Entrevista concedida ao Projeto de Pesquisa: Memórias da terra: Modos de viver lutas e resistências camponesas no Oeste e Sudoeste do Paraná. Por Francieli Pinheiro, Paulo José Kolling e Tiago A. Orben. Perímetro urbano. Verê/Paraná: 21 de maio de 2011, duração: 74 min. 49 seg. p. 13.
} 
seu futuro marido, porém após um primeiro encontro seu pretendente viaja para Santa Catarina.

Noto que Inês mostra-se muito espontânea ao revelar suas vivências. Quando lhe é dirigida a questão “quem propôs o namoro?", decide contar o momento em que seu Jardelino retorna para Verê, possibilitando o início do relacionamento:

Mas eu vou contá essa história é muito bonita. [risos!] Nem quero lembrar [cochicha somente para si, rindo]. Ele foi embora pra Santa Catarina, ficou um ano e seis meses pra lá, e quando ele voltou, foi no dia da primeira crisma aqui no Verê, da paróquia de Verê, que deu a primeira crisma que veio o bispo crismá, o pessoal que vieram de Dois Vizinhos, de tudo que for recanto porque era aqui a crisma que ia ter, e em outras localidades não ia ter durante o ano, então veio. E nós nos encontramos, quando eu ia descendo na rua, eu e uma amiga minha, as outras que tavam numa sombra ali do antigo Sindicato elas disseram: "olha lá teu Néli", porque o apelido dele era Néli. Eu olhei, ele tava na janela da casa da irmã dele lá, e deu aquele sorriso!. E eu sabia que ele ia casar em maio, e era agosto já, eu disse: "Mas cale a boca infames que ele tá casado!", e ele olhando pra nós e rindo, e digo: "agora tá fazendo gozação de mim, que tristeza!”, pensei [risos], e não era casado não, desceu de lá, a minha amiga que tava junto comigo, fez sinal pra ele desce, mas por causa dela. Porque ela já tinha sido paquera dele, e ele não veio procurá ela, foi procurar eu, e nós fomos lá paremos numa sombra e eu mandava ela olhá pra trás vê se eles vinham vindo, porque eu não queria olhá. Ela disse: "vem vindo, eles vem vindo", chegamos lá naquela sombra, ela ficou, eu fiquei na sombra de uma casa, era um açougue, ela na sombra de uma árvore mais do ladinho. Aí ele chegou e foi lá onde eu tava, e o outro que tava um "boca mole" foi lá com ela, foi a maior tristeza [risos!] pra ela. Daí nós começamos e continuamos até casar. ${ }^{23}$

Dona Inês nos revela uma memória muito pessoal, recorda detalhes de como seu relacionamento com seu Jardelino teve início. Também apresenta como acontecia a vida social no encontro com "as amigas" e os "namoros", sempre ligados à vida religiosa das comunidades. No caso, tanto quando conheceu seu Jardelino, quanto ao iniciar o namoro, ambos acontecem em eventos relacionados à igreja católica, que tem forte presença no município. Também vejo o apresentar uma memória tão pessoal ligada ao recente falecimento de seu Jardelino em 2009, percebo que durante toda a entrevista recorda seu marido, e que sua ausência ainda estava muito presente no seu dia a dia.

Neste sentido, pode-se considerar que o relato acima provavelmente não seria revelado se seu esposo ainda estivesse vivo. A ausência de seu

${ }^{23}$ Ibidem, p. 13, 14. 
Jardelino, e o forte sentimento entre eles, a fez refletir sobre aquilo que vivenciaram mesmo antes do depoimento. Neste intervalo entre a perda de seu marido e a entrevista, possivelmente sua memória relacionada a momentos felizes junto a ele já havia retornado inúmeras vezes ao momento em que se conheceram. Deste modo, seu depoimento, no contexto em que é apresentado, não é apenas um recordar junto ao contexto sugerido pelos entrevistadores, mas, um recordar recente, em que sua memória recente a faz refletir sobre momentos felizes e tristes vividos por ela e seu esposo.

Tais considerações demonstram como o trabalho de Halbwachs foi importante para refletir como, ao trabalhar com história oral, devemos estar atentos aos movimentos da memória dos entrevistados, visto que a lembrança não se constitui apenas no presente, mas, como já observado por Bergson e Halbwachs, com características específicas, seja em quadros sociais, na coletividade ou mesmo enquanto construção.

Assim, ao pensar uma análise em que considere a produção dos relatos orais junto à memória, destaco o trabalho de Alessandro Portelli, "A filosofia e os fatos: Narração, interpretação e significado nas memórias e nas fontes orais":

A história oral e as memórias, pois, não nos oferecem um esquema de
experiências comuns, mas sim um campo de possibilidades compartilhadas,
reais ou imaginárias. A dificuldade para organizar estas possibilidades em
esquemas compreensíveis e rigorosos indica que, a todo momento, na mente
das pessoas se apresentam diferentes destinos possíveis.

Portelli é pontual ao destacar que a história oral não nos oferece apenas experiências comuns e aponta o grande campo de possibilidades compartilhadas, "reais ou imaginárias". Procura explicar os exemplos que cita em seu texto, seja no caso de Frederick Douglass ou no caso dos operários de Térni. Indicando o trabalho da mente na produção do relato oral, ao apresentar diferentes destinos possíveis pautados em "esquemas possíveis e rigorosos".

Assim, ao pensar o contexto de produção do relato oral e os movimentos da memória, destaco que as experiências não são experiências comuns, mas sim, experiências refeitas no presente, ou seja, a produção de um relato junto a questões do presente.

Isso ganha força em relação aos significativos movimentos comemorativos que aconteceram no Sudoeste do Paraná, que não fazem apenas os

${ }^{24}$ PORTELLI, Alessandro. "A filosofia e os fatos. Narração, interpretação e significado nas memórias e nas fontes orais”. In: Tempo. Rio de Janeiro, UFF, 1996, Vol. 1, no 2, p. 59-72. 
sujeitos da Revolta reelaborar o passado por meio da memória, mas, sim, eles a processam no presente, de questões recolocadas em pauta no presente. Como Portelli aponta, as experiências das pessoas apresentam diferentes caminhos, em relação ao presente e a produção da memória.

Junto a este contexto e ainda refletindo o depoimento de dona Inês, quando trabalhamos questões relacionadas a 1957, suas recordações são mais sucintas, ou, pelo menos, não se atêm muito ao levante. Sempre que lhe era dirigida uma questão sobre o levante dos colonos no município de Verê, descrevia com receio e era muito sucinta:

Entrevistador: A senhora lembra de algum conflito que teve entre os funcionários da CITLA?

Inês: Não, não dessa parte.

Entrevistador: Mandavam cobrar dos colonos, eles queriam vender e cobrar de novo e cobrar bastante?

Inês: Não. Não tive conhecimento dessa parte. ${ }^{25}$

É perceptível que ao mesmo tempo em que a entrevistada demonstra ter muitas memórias da década de 50 , tanto com relação às experiências comunitárias, conforme descrito, ao conhecer seu marido, período de namoro, noivado e casamento, também, em inúmeros outros momentos em que relata suas vivências com seu pai, o qual igualmente apresenta uma relação afetiva muito próxima, expõe poucas memórias, ou pelo menos não as revela em detalhes, relacionadas ao levante, apenas responde as indagações de forma sucinta, ou, quando não discorda, apenas afirma que não tem "conhecimento", pelo menos "dessa parte".

Por outro lado, conhecendo a proximidade que seu falecido marido tinha com o vereador Pedrinho Barbeiro, questionamos sobre os acontecimentos envolvendo o vereador. Com isso, dona Inês destaca um depoimento com mais detalhes:

Porque, que ele foi assassinado, porque ele defendia os colonos. Defendia os colonos desses que tavam querendo medir e cobrar e não, e ele dizia que não era legal. Então ele ajudava os colonos. Esclarecia pros colonos que não era, que isso ali não era verdade. Era uma força, porque os colonos também não entendiam sabe se é ou não é, e ele como tinha esclarecimento, ele esclarecia para os colonos que não era verdade essa, ele ajudava e combatia. ${ }^{26}$

\footnotetext{
${ }^{25}$ GUANDALIN, Inês Moraes. Entrevista concedida ao Projeto de Pesquisa: Memórias da terra: Modos de viver lutas e resistências camponesas no Oeste e Sudoeste do Paraná. Por Francieli Pinheiro, Paulo José Kolling e Tiago A. Orben. Perímetro urbano. Verê/Paraná: 21 de maio de 2011, duração: 74 min. 49 seg. p. 18.

${ }^{26}$ Ibidem, p. 18.
} 
Este trecho é apresentado após a seguinte questão; "por que o vereador Pedrinho foi assassinado?". o que mais chama atenção é que a entrevistada, neste momento, apresentava expressões sérias, ao mesmo tempo em que trazia características exaltando a figura do vereador assassinado como uma "força" para os colonos. Assim como apresentou seu Osvaldo, novamente o vereador Pedro José da Silva é visto como uma referência para os colonos do município de Verê, como aquele que "esclarecia pros colonos que isso ali não era verdade". Isso explica por meio de experiências de pessoas simples, que não participaram diretamente dos acontecimentos do levante, como a figura do vereador foi uma referência para os colonos de Verê.

Com isso, destaco que existe a elaboração de uma memória da importância do que foi a morte do vereador para o desfecho do movimento. $O$ vínculo pessoal que seu falecido marido tinha com o vereador e a importância que a morte deste dá ao levante de 1957, junto aos sentidos e reelaborações que estes acontecimentos têm no presente, colaboram para que o depoimento de dona Inês apresente este forte conteúdo sentimental.

Dentre os entrevistados que possuem características neste sentido, destaco o depoimento do senhor João Miolla ${ }^{27}$, que apresenta memórias de quem viveu os acontecimentos envolvendo o litígio da terra em sua juventude, expondo uma percepção diferente, enquanto um mero expectador, demonstrando como a instabilidade social manifestava-se para sua família.

Seu depoimento tem como característica a descrição a partir do ouvir falar, e também de como viveu algumas experiências nos dias decisivos do levante. Neste sentido, selecionei pequenos fragmentos em que expressa a ação das companhias e a posição do governo do estado frente à questão. Em relação às companhias, Miolla aponta para a CITLA - já que esta atuara na região de Francisco Beltrão e Verê -, com ênfase para a aproximação e sua percepção em relação à companhia:

Eu devia de ter lá, uns 14, 15 anos quando, é em 57. Se via falar, vinha um aviãozinho ele era vermelho por baixo, se dizia que era o avião da CITLA. A palavra CITLA, não sei por que se dizia CITLA, mas em fim que era, e aquele tempo lá eles falavam em jagunço, porque eles eram malvados, mataram muita gente, tem muita história feia. ${ }^{28}$

\footnotetext{
${ }^{27}$ João Miolla é natural de Cacique Doble/RS, a família de seu pai chega à Verê em 1944, quando o entrevistado tinha apenas 3 anos de idade.

${ }^{28}$ MIOLLA, João. Entrevista concedida ao Projeto de Pesquisa: A Revolta dos Colonos outras memórias. Por Tiago A. Orben. Município de Verê, perímetro urbano. Verê/PR, 3 de setembro de 2013, duração: 1h $11 \mathrm{~min} .11$ seg. p. 2.
} 
A descrição de Miolla tenta expressar aquilo que ele conhecia em relação às companhias, porém apenas descreve que se tratava da CITLA, e de que ela tinha um avião que usava para fiscalizar as terras. Além disso, "falavam em jagunço", ou seja, o entrevistado conduz seu depoimento com referência ao que era repassado a sua família, e não exatamente de experiências vividas pelo próprio. Aspecto que não desqualifica seu depoimento, já que era jovem quando o levante aconteceu, e que, mesmo assim, demonstra conhecer o litígio da terra e de que forma o estado era conivente.

Tais aspectos são explorados no momento em que tenta descrever o confronto entre colonos e funcionários das companhias em Verê e na comunidade de Alto Verê. Sua descrição ampara-se em sua experiência pessoal, e também em forma de denúncia, ao lembrar que a polícia, e, automaticamente, o governo do estado, eram favoráveis às companhias:

Nós tava lá em casa e nós pensava e se reunimos, uns 10,12 piá, tudo mais ou menos dessa idade, quem de 10 anos até, tinha alguns mais velhos, tinha uns primos meus que já tavam com uns 17, 18 anos, já era moço. E planejava de se esconder no mato, se viesse, se visse alguém, mas com um barulhão daquele, foi muito feio aquele tiroteio. Eu não sei quanto que durou, lá eles se atiravam com a polícia, a polícia tava a favor deles, agora aqui no Verê não, aqui foi só os colonos. ${ }^{29}$

Essa descrição não apenas recoloca mais um sujeito que presenciou o medo e a insegurança no litígio da terra em 1957, mas, também, demonstra como o Estado era omisso, e de que forma a polícia fazia-se presente em defesa das companhias. Ou seja, servidores públicos a serviço de interesse privado, característica que dificilmente é lembrada nas "celebrações comemorativas" da Revolta, e que a singularidade da fonte oral possibilita.

Miolla, como os outros entrevistados, além do medo e da insegurança, também apresenta vivências felizes neste mesmo período. Como exemplo, destaco o momento em que aborda como foi a formação das primeiras comunidades rurais e o período em que começa a cantar e tocar, justamente o mesmo do levante:

João Miolla: Olha eu tava assim[...] Com uns 14 anos eu já cantava, tinha um violãozinho, mas quando eu comecei a tocar baile eu tinha uns 16 anos.

Entrevistador: Então naquela época nos anos 50 já começou?

João Miolla: Sim! Foi mais ou menos aqueles tempos que eu comecei, já cantava!

Entrevistador: E como que eram as festas aquela vez?

${ }^{29}$ Ibidem, p. 3. 
João Miolla: Há! Aquela vez a maioria era assim, bailinho de casa, mas já dava festinha assim de comunidades. Tipo o Verezinho já tinha uma pequena igreja e depois foi saindo nas outras comunidades, no Alto Verê tinha uma pequena igreja e assim foi saindo, foi formando as outras comunidades tipo Planalto já saiu, já faz anos que saiu igreja. Lambedor, que Lambedor foi sempre uma das comunidades, das maiores, que nós tinha aqui, dentro do município. ${ }^{30}$

É interessante observar como João Miolla reconhece a década de 50, a mesma do levante, na qual inicia sua carreira como cantor e violeiro. Neste ponto, noto que apesar de reconhecer o mesmo período, não faz relação entre eles, recorda os bailes ainda realizados em casas, e a formação das primeiras comunidades rurais como: "Verezinho", "Alto Verê", "Planalto" e "Lambedor", as quais, posteriormente com a implantação das primeiras igrejas, possibilitam, nessas festas comunitárias, que Miolla divulgue seu trabalho por meio da música, sendo que, desta forma, ele acaba ganhando reconhecimento no município.

Com este contexto destaco como vivências de pessoas simples, como as de João Miolla, Osvaldo e dona Inês, possuem lembranças recheadas de significados e emoções, apresentadas com espontaneidade. Recordar a Revolta ou os acontecimentos da década de 50 não é apenas repensar os acontecimentos do levante, mas, recordar a partir das vivências ou experiências sociais vividas por cada indivíduo, dona Inês e seu Osvaldo não relembram apenas a morte de Pedrinho Barbeiro em um contexto de luta pela terra, mas, o reflexo direto deste assassinato em suas vidas cotidianas.

Considerar suas trajetórias de vida visualizando o conflito como um evento dentro dela difere de considerar o conflito e seu significado para sua vida. Assim, esta reflexão propôs pensar as experiências no sentido amplo, não apenas o levante e o quanto isso foi bom para eles, mas, em sentido diverso, pensando suas vidas e o quanto os acontecimentos de 1956 e 1957 se refletiram no dia a dia.

\section{Considerações finais}

O principal objetivo neste artigo ao apresentar diferentes experiências foi, não só privilegiar os eventos já conhecidos em âmbito regional e nacional, mas também, as experiências simples, de pessoas que viveram momentos de instabilidade política e social, junto as suas vivências cotidianas em comunidade.

${ }^{30}$ Ibidem, p. 5. 
Destarte, merece destaque as poucas produções com fontes orais sobre a luta social de 1957. O tema apresenta outras possibilidades de trabalhos, que possam privilegiar as experiências de outros sujeitos em que o litígio da terra se fez presente na década de 50 . O que pode ser observado também, ao lado das ainda constantes apropriações da Revolta, que todo ano apresentam-se por meio de diferentes facetas; em especial, nas principais cidades da região hoje - Francisco Beltrão e Pato Branco - nas quais também se observa a constante apropriação político partidária.

O que foi evidenciado nas trajetórias acima apresentadas são as vivências elaboradas pela memória dos entrevistados, seu reconhecimento e sua identificação com os acontecimentos de 1957. Como exemplo, destaco que seu Osvaldo elabora considerações com referência a sua realidade familiar, sempre com uma atenção especial aos acontecimentos em relação à posse da terra. Já dona Inês opta por um depoimento com memórias felizes, esquivando-se, na medida do possível, das indagações sobre a Revolta.

No trabalho com fontes orais, devemos observar esses "percursos" da memória elaborados no presente. Portelli, em seu artigo "O que faz a história oral diferente," apresenta um item para ponderações relacionadas à história oral como narrativa. Neste sentido, alerta para uma questão que possibilita reflexão, expõe que "um informante pode relatar em poucas palavras experiências que duraram longo tempo ou discorrer minuciosamente sobre breves episódios". ${ }^{31}$

As colocações de Portelli elencam alguns pontos apresentados, tais como os longos relatos que Osvaldo elabora sobre a Revolta de $1957 \mathrm{no}$ município de Verê, ao mesmo tempo em que Inês pouco fala, praticamente abstendo-se a respeito deste ponto. Da mesma forma, percebo o contrário, com a entrevistada prolongando-se em acontecimentos familiares com forte conteúdo sentimental, enquanto Osvaldo evita tais questões. Portelli ainda alerta que "em todos os casos, há uma relação entre a velocidade da narração e a intenção do narrador". Considerando tais colocações, a história oral como narrativa oferece um grande campo reflexivo, o qual deve sempre ser considerado pelo historiador oral, que no exemplo exposto é importantíssimo para a compreensão.

Antes de encerrar, ainda apresento mais uma pequena consideração de Portelli, que demonstra como eventos e significados podem ter sentidos diferentes quando aplicados à história a partir de depoimentos orais:

${ }^{31}$ PORTELLI, Alessandro. "O que faz a história oral diferente”. In: Projeto História. São Paulo, 1997, Vol. 1, n 14, p. 29. 
A primeira coisa que torna a história oral diferente, portanto, é aquela que nos conta menos sobre eventos que sobre significados. Isso não implica que a história oral não tenha validade factual. Entrevistas sempre revelam eventos desconhecidos ou aspectos desconhecidos de eventos conhecidos: elas sempre lançam nova luz sobre áreas inexploradas da vida diária das classes não hegemônicas. ${ }^{32}$

Essas colocações fazem recordar o depoimento de dona Inês, o qual talvez não diga tanto sobre os eventos de 1957, e isso demonstre justamente o que aquilo significa em sua vida, e que não seja agradável relembrar. A entrevistada prefere lembranças familiares, momentos felizes junto ao seu círculo afetivo. $O$ evento que nos leva até ela e que a faz recordar são os acontecimentos de 1957, mas os significados que ela atribuiu para suas memórias são outros.

As colocações de Portelli também podem ser relacionadas ao depoimento de Osvaldo, quando "sempre revelam eventos desconhecidos ou aspectos desconhecidos de eventos conhecidos". ${ }^{33}$ O entrevistado revela "o que apoiô os colonos, que apoiava era o falecido Pedrinho e o Vasco, um que tinha uma camioneta, aquele Vasco, aquele alemão". ${ }^{34}$ O sujeito chamado "Vasco" era um nome desconhecido até então nos acontecimentos de 1957 ocorridos em Verê, temos aqui eventos conhecidos, que ganham novos significados com as fontes orais. Como Portelli acrescenta, as entrevistas orais "lançam sempre nova luz" às experiências analisadas.

Em relação às experiências apresentadas, o objetivo foi expor brevemente os múltiplos significados e sentidos que as fontes orais possibilitam, para tanto trouxe para reflexão as diferentes vivências presentes nos depoimentos, vivências essas relacionadas tanto ao círculo familiar dos entrevistados, como dos episódios relacionados ao litígio da terra. É justamente esta multiplicidade de memórias que "faz a história oral diferente", e que possibilita conhecer os eventos ou a Revolta de 1957, para além daquilo que é constantemente apresentado na historiografia regional.

Artigo recebido para publicação em 29/09/2015

Artigo aprovado para publicação em 24/03/2016

\footnotetext{
${ }^{32}$ Ibidem, p. 31.

${ }^{33}$ Ibidem, p. 31.

${ }^{34}$ FERREIRA DA SILVA, op. cit., p. 8.
} 